\title{
Konseling Kognitif Behavioral Dengan Teknik Self Management dan Teknik Modeling Terhadap Motivasi Berprestasi Ditinjau dari Tipe Belajar
}

\author{
Ni Wayan Karyani ${ }^{1}$, I Ketut Dharsana ${ }^{2}$ \\ ${ }^{12}$ Universitas Pendidikan Ganesha \\ e-mail: iketut.dharsana@undiksha.ac.id
}

Received March 01, 2018; Revised April 01, 2018; Accepted Mei 01, 2018; Published Online June, 302018

\section{Conflict of Interest} Disclosures:

The authors declare that they have no significant competing financial, professional or personal interests that might have influenced the performance or presentation of the work described in this manuscript.

\begin{abstract}
The purpose of this research for to known the effectiveness of cognitive behavioral counseling with Self Management Technique and Modeling Technique toward Need for Achievment Reviewed on Studying Type. This research design by two factor design. The sampling are 90 person students of X grade SMA Negeri 1 Kintamani academic year 2015/2016 and analyzed by analysis of varians (anava) and Tukey. The result of the research is: (1) there are a difference of need for achievement between students who follows humanistic counseling with self management technique with students who follows modeling.technique.; (2) there are a difference of need for achievement reviewed of studying type. (3) there are an interactions effect of humanistic counseling with self management technique and modeling technique with studying type of need for achievement.; (4) there are a difference of need for achievement between students who follows humanistic counseling with self management with students who follows modeling technique on students based auditory studying type; (5) there are no difference of need for achievement between students who follows humanistic counseling with self management technique with modeling technique on students based visual studying type; (6) there are no difference of need for achievement between students who follows self management technique with modeling technique on students based kinesthetic.
\end{abstract}

Keywords: Self Management, Modeling, Cognitive Behavioral Counseling, Need for Achievement
This is an open access article distributed under the Creative Commons 4.0 Attribution License, which permits unrestricted use, distribution, and reproduction in any medium, provided the original work is properly cited. (C2018 by author
How to Cite: Karyani, N. W., \& Dharsana, I.K. 2018. Konseling Kognitif Behavioral Dengan Teknik Self Management dan Teknik Modeling Terhadap Motivasi Berprestasi Ditinjau dari Tipe Belajar. Bisma. 2 (1): pp. 31-38, DOI: 10.24036/XXXXXXXXXX-X 


\section{Pendahuluan}

Dalam sebuah lembaga pendidikan, bimbingan dan konseling merupakan suatu komponen yang sangat penting untuk memajukan mutu sebuah sekolah. Karena jika kita lihat pada masyarakat pada umumnya sebuah sekolah atau lembaga pendidikan secara umum dapat dikatakan berkualitas dengan cara melihat output yang dihasilkan oleh sebuah sekolah, dalam arti kata masyarakat akan menganggap sebuah sekolah itu berkualitas apabila siswa atau peserta yang dihasilkan memiliki kualitas dan memenuhi harapan sesuai yang masyarakat inginkan. Dalam kegiatan proses pembelajaran di sekolah tidak jarang banyak permasalahan yang sering dihadapi oleh siswa. Suarni (dalam Dharsana, $2014: 1$ ) mengungkapkan bahwa, "siswa cenderung mengalami kemundurun dalam prestasi belajarnya, disebabkan oleh pernyataanpernyataan negatif terhadap tugas-tugas pelajaran di sekolah. Mereka lebih cenderung memvonis lingkungan dengan pernyataan negatif daripada berusaha untuk mengembangkan pernyataan positif terhadap tugastugas yang dihadapinya. Untuk mengikuti proses pendidikan yang panjang dengan segala kompleksitas permasalahan yang muncul di dalamnya, diperlukan berbagai perangkat yang memadai, yaitu salah satunya yang penting adalah motivasi berprestasi yang perlu dimiliki oleh setiap siswa. Dharsana (2014) menyatakan motivasi berpestasi adalah kebutuhan untuk berprestasi yang meliputi: (1) menyelesaikan sesuatu dengan baik dan akan berhasil, (2) menyelesaikan tugas dan memerlukan usaha diikuti keahlian dan keterampilan (3) Menyelesaikan sesuatu yang penting (4) Melaksanakan suatu pekerjaan yang sulit (5) Mampu melakukan sesuatu yang lebih baik dari orang lain. Menurut McCelland (dalam Robbins dan Judge: 2007) mengatakan motivasi berprestasi adalah proses pembelajaran yang stabil yang mana kepuasan akan didapatkan dengan berjuang dan memenuhi level tertinggi untuk dapat menjadi ahli dibidang tertentu. Pendapat lainnya mengatakan bahwa motivasi berprestasi adalah keinginan untuk menantang pekerjaan/tugas yang sulit, yang mana orang yang memiliki motivasi berprestasi yang tinggi memiliki kontrol terhadap prilaku mereka dan menyukai tantangan yang sulit, sementara individu yang memiliki motivasi berprestasi yang rendah mudah puas dengan tantang yang sedikit (Aamodt, 1991 dalam Santrok 2003). Hal ini dijelaskan kembali oleh Santrok (2003) yang mengatakan bahwa motivasi berprestasi adalah keinginan untuk mencapai sesuatu, mencapai standar kemahiran dan meluaskan usaha untuk menjadi ahli. Dari pendapat-pendapat para ahli tersebut, dapat disimpulkan bahwa motivasi berprestasi adalah suatu dorongan untuk meningkatkan kemampuan dalam hal pencapaian prestasi diantaranya adalah menyukai tugas yang sulit dan menantang, memiliki kemandirian tinggi, memiliki sasaran dan tujuan yang jelas, mempertimbangkan keahlian yang harus dicapai, dan mampu cepat bangkit dari kegagalan.Terdapat faktor-faktor yang mempengaruhi motivasi berprestasi, meliputi faktor individual (internal) dan faktor lingkungan (eksternal). Dalam hal ini, faktor individual yang dimaksud terutama adalah faktor intelegensi dan faktor penilaian individu tentang dirinya. Selain hal itu Self-efficacy juga mempengaruhi motivasi berprestasi seseorang, Self-efficacy adalah keyakinan yang dimiliki oleh seseorang untuk melakukan suatu tugas. Bandura mengatakan bahwa prilaku manusia adalah proses pengendalian pikiran yang dapat memicu motivasi untuk melakukan tugas yang menantang serta tipe belajar yang dimiliki oleh siswa yang beranekaragam juga dapat mempengaruhi motivasi berprestasi Faktor lingkungan adalah segala sesuatu yang berada diluar diri individu, yang turut mempengaruhi motivasi berprestasinya. Faktor lingkungan ini dibagi menjadi 3 , yaitu ; lingkungan keluarga, lingkungan sosial, dan lingkungan akademik. Setelah diadakan pengamatan langsung yang cukup intens pada siswa kelas X SMA Negeri 1 Kintamani selama satu bulan dan mengadakan wawancara kepada beberapa siswa, masih banyak ditemukan siswa yang belum memahami mengenai motivasi berprestasi dan kalaupun telah memiliki motivasi berprestasi, motivasi berprestasi tersebut masih rendah. Sehingga banyak siswa yang memiliki masalah diantaranya kurang adalah menyukai tugas yang sulit dan menantang, tidak memiliki kemandirian tinggi, tidak memiliki sasaran dan tujuan yang jelas, tidak mampu mempertimbangkan keahlian yang harus dicapai, dan kurang mampu cepat bangkit dari kegagalan. 
Teori konseling memang banyak sekali seperti teori konseling psikoanalisa, client-centered, gestalt, trait and factor, analisis transaksional, kognitif behavioral, dan kognitif behavioral. Dari sekian teori konseling yang ada, maka peneliti mencoba untuk melihat efektivitas dari teori kognitif behavioral terhadap motivasi berprestasi. Teori konseling kognitif behavioral adalah suatu pendekatan yang memandang bahwa seorang individu memiliki perilaku yang dipengaruhi oleh kondisi kognitif (pikiran). Konseling kognitif behavioral menekankan bahwa perubahan tingkah laku dapat terjadi jika seseorang individu mengalami perubahan dalam kognitifnya. Aaron T. Beck (dalam Corey: 2003) mendefinisikan konseling kognitif behavioral atau sering disebut cognitive behavioral therapy (CBT) sebagai pendekatan konseling yang dirancang untuk menyelesaikan permasalahan konseli dengan cara melakukan restrukturisasi kognitif dan perilaku yang menyimpang. Konseling kognitif behavioral didasarkan pada formulasi/susunan kognitif, keyakinan dan strategi perilaku yang mengganggu. Proses konseling didasarkan pada konseptualisasi atau pemahaman konseli atas keyakinan khusus dan pola perilaku konseli. Harapan dari konseling kognitif behavioral yaitu munculnya restrukturisasi kognitif dari perilaku menyimpang dan sistem kepercayaan untuk membawa perubahan emosi dan perilaku ke arah yang lebih baik. Konseling kognitif behavioral diarahkan pada modifikasi fungsi berfikir, merasa, dan bertindak dengan menekankan peran otak dalam menganalisa, memutuskan, bertanya, bertindak, dan memutuskan kembali. Dengan mengubah status pikiran dan perasaannya, konseli diharapkan dapat mengubah tingkah lakunya, dari negatif menjadi positif. Konseling kognitif behavioral memiliki banyak teknik yang dapat diterapkan kepada siswa untuk melihat efektivitasnya terhadap motivasi berprestasi namun peneliti memilih teknik yang peneliti anggap cocok digunakan untuk meilhat efektivitasnya terhadap motivasi berprestasi siswa di sekolah, yaitu teknik self management dan teknik modeling. Self-management adalah sebuah teknik yang diberikan kepada individu untuk membantu individu tersebut mengatur, mengelola serta mengarahkan dirinya. Kemampuan mengatur diri dapat mencegah individu dari keadaan malasuai atau penyimpangan kepribadian. Dalam penggunaan strategi ini diharapkan konseli dapat mengatur, memantau dan mengevaluasi dirinya sendiri untuk mencapai perubahan kebiasaan tingkah laku yang lebih baik. Berikut beberapa pendapat dari para ahli tentang konsep self-management : Menurut Gunarsa (2004: 223) mengemukakan bahwa "pengelolaan diri (self management) adalah prosedur dimana klien menggunakan keterampilan dan teknik mengurus diri untuk menghadapi masalahnya, yang dalam terapi tidak langsung diperoleh". Keterampilan tersebut diperoleh pada saat proses konseling karena perubahan dalam perilaku itu harus diusahakan melalui suatu proses belajar (learning) atau belajar kembali (relearning). Sedangkan menurut Nursalim (2013: 149) bahwa "selfmanagement adalah suatu proses di mana konseli mengarahkan perubahan tingkah laku mereka sendiri, dengan menggunakan satu strategi atau kombinasi strategi". Jadi dalam proses konseling walaupun konselor yang mendorong dan melatih prosedur ini, tetapi konselilah yang tetap mengontrol pelaksanaannya. Sehingga dari sinilah konseli mendapat suatu ketrampilan untuk mengurus diri. Strategi tersebut terdapat tiga macam yaitu self-monitoring (memonitor diri), stimulus-control, dan self-reward (ganjar diri). Modeling adalah sebuah teknik dengan cara melakukan peniruan tingkah laku seseorang baik secara langsung maupun dari peniruan symbolic. Istilah modeling merupakan istilah umum untuk menunjukkan terjadinya proses belajar melalui pengamatan dari orang lain dan perubahan yang terjadi karenanya melalui peniruan. Modeling merupakan salah satu teknik konseling yang dikembangkan oleh Albert Bandura yang berakar dari teori belajar sosial (sosial lerning). Menurut Bandura (dalam Corey (dalam terjemahan E. Koswara, 1988: 221) "teknik modeling merupakan observasi permodelan, mengobservasi seseorang lainnya sehingga seseorang tersebut membentuk ide dan tingkah laku, kemudian dijelaskan sebagai panduan untuk bertindak". Bandura juga menegaskan bahwa modeling merupakan konsekuensi perilaku meniru orang lain dari pengalaman baik pengalaman langsung maupun tidak langsung, sehingga reaksi-reaksi emosional dan rasa takut seseorang dapat dihapuskan. Sedangkan Gantina Komalasari dkk (2011:176) mengartikan "modeling merupakan belajar melalui observasi dengan menambahkan atau mengurangi tingkah laku yang teramati, menggeneralisir berbagai pengamatan sekaligus, dan melibatkan proses kognitif". Menurut Perry dan Furukawa (dalam Sopya, 2013: 29) mendefinisikan "modeling sebagai proses belajar melalui observasi dimana tingkah laku dari seorang individu atau kelompok, sebagai model, berperan sebagai rangsangan bagi 
pikiran-pikiran, sikap-sikap, atau tingkah laku sebagai bagian dari individu yang lain yang mengobservasi model yang ditampilkan". Berdasarkan beberapa pendapat diatas dapat disimpulkan bahwa modeling merupakan salah satu teknik konseling dimana seseorang belajar membuat dan menerapkan perilaku baru melalui proses pengamatan, mengobservasi, menggeneralisir perilaku orang lain (model), dimana dalam modeling ini juga melibatkan proses kognitif dan kreatif bukan semata-mata meniru/imitasi saja. Suatu hal yang perlu kita ketahui bersama adalah bahwa setiap manusia memiliki cara menyerap dan mengolah informasi yang diterimanya dengan cara yang berbeda satu sama lainnya. Ini sangat tergantung pada tipe belajarnya. Berdasarkan Sukadi (2011:93) mengatakan bahwa "tipe belajar yaitu kombinasi antara cara seseorang dalam menyerap pengetahuan dan cara mengatur serta mengolah informasi atau pengetahuan yang didapat." Sedangkan menurut S. Nasution (2014: 94), "tipe belajar adalah cara yang konsisten yang dilakukan oleh seorang murid dalam menangkap stimulus atau informasi, cara mengingat, berpikir, dan memecahkan soal". Menurut DePorter \& Hernacki (2009:10) "tipe belajar merupakan suatu kombinasi dari bagaimana ia menyerap, dan kemudian mengatur serta mengolah informasi." Menurut Fleming dan Mills, "tipe belajar merupakan kecenderungan siswa untuk mengadaptasi strategi tertentu dalam belajarnya sebagai bentuk tanggung jawabnya untuk mendapatkan satu pendekatan belajar yang sesuai dengan tuntutan belajar di kelas/sekolah maupun tuntutan dari mata pelajaran." Menurut Bobbi De Poter \& Mike Hernacki secara umum tipe belajar manusia dibedakan ke dalam tiga kelompok besar, yaitu tipe belajar auditori, tipe belajar visual dan tipe belajar kinestetik.

Berdasarkan latar belakang di atas ada beberapa masalah yang dapat diidentifikasi antara lain : (1) Motivasi berprestasi siswa di sekolah sangat beragam, ada yang tinggi, sedang maupun rendah. (2) Belum banyak siswa yang mengetahui pentingnya manfaat meningkatkan Motivasi Berprestasi di sekolah (3) Belum banyak siswa yang mengetahui cara-cara atau kiat-kiat untuk meningkatkan motivasi berprestasi siswa (4) Belum banyak siswa yang mengetahui kecenderungan tipe belajarnya apakah dia kenderung memiliki tipe belajar auditori, visual maupun kinestetis (5) Belum banyak siswa yang mengetahui bahwa kecenderungan tipe belajar yang mereka miliki akan mempengaruhi motivasi berprestasi. Motivasi berprestasi adalah suatu dorongan untuk meningkatkan kemampuan dalam hal pencapaian prestasi diantaranya adalah menyukai tugas yang sulit dan menantang, memiliki kemandirian tinggi, memiliki sasaran dan tujuan yang jelas, mempertimbangkan keahlian yang harus dicapai, dan mampu cepat bangkit dari kegagalan. Orang yang memiliki motivasi berprestasi yang tinggi memiliki kontrol terhadap prilaku mereka dan menyukai tantangan yang sulit, sementara individu yang memiliki motivasi berprestasi yang rendah mudah puas dengan tantang yang sedikit. Banyak faktor yang mempengaruhi Motivasi berprestasi tersebut, baik faktor dari luar individu maupun faktor dari dalam diri individu. Tipe belajar yang dimiliki individu merupakan salah satu faktor yang mempengaruhi motivasi berprestasi seseorang. Teori konseling kognitif behavioral adalah suatu pendekatan yang memandang bahwa seorang individu memiliki perilaku yang dipengaruhi oleh kondisi kognitif (pikiran). Konseling kognitif behavioral merupakan konseling yang menitik beratkan pada restrukturisasi atau pembenahan kognitif yang menyimpang akibat kejadian yang merugikan dirinya baik secara fisik maupun psikis dan lebih melihat ke masa depan dibanding masa lalu. Aspek kognitif antara lain mengubah cara berpikir, kepercayaan, sikap, asumsi, imajinasi dan memfasilitasi konseli belajar mengenali dan mengubah kesalahan dalam aspek kognitif. Sedangkan aspek behavioral yaitu mengubah hubungan yang salah antara situasi permasalahan dengan kebiasaan mereaksi permasalahan, belajar mengubah perilaku, menenangkan pikiran dan tubuh sehingga merasa lebih baik, serta berpikir lebih jelas. 
Self-management (pengelolaan diri) sama artinya dengan kemampuan mengatur diri dan mengarahkan diri. Kemampuan mengatur diri dapat mencegah individu dari keadaan malasuai atau penyimpangan kepribadian. self-management adalah suatu proses di mana konseli mengarahkan perubahan tingkah laku mereka sendiri, dengan menggunakan satu strategi atau kombinasi strategi. self-management bagi seseorang bertujuan mendorong diri sendiri untuk maju, untuk dapat mengatur, memantau dan mengevaluasi dirinya sendiri dalam mencapai perubahan kebiasaan tingkah laku yang lebih baik dalam kehidupan pribadi. Sedangkan modeling merupakan salah satu teknik konseling dimana seseorang belajar membuat dan menerapkan perilaku baru melalui proses pengamatan, mengobservasi, menggeneralisir perilaku orang lain (model), dimana dalam modeling ini juga melibatkan proses kognitif dan kreatif bukan semata-mata meniru/imitasi saja. Suatu hal yang perlu kita ketahui bersama adalah bahwa setiap manusia memiliki cara menyerap dan mengolah informasi yang diterimanya dengan cara yang berbeda satu sama lainnya. Ini sangat tergantung pada tipe belajarnya. tipe belajar adalah sebuah cara atau kecenderungan seseorang mengenai bagaimana ia belajar. Menurut Bobbi De Porter \& Mike Hernacki (dalam Suyono \& Hariyanto: 2012) secara umum tipe belajar manusia dibedakan ke dalam tiga kelompok besar, yaitu tipe belajar auditori, tipe belajar visual dan tipe belajar kinestetik.

\section{Metode}

Penelitian ini merupakan penelitian quasi eksperimen yang sering juga disebut penelitian eksperimen semu. Rancangan eksperimen yang digunakan dalam penelitian ini adalah adalah the posttes-only control group design. Penelitian ini menggunakan rancangan penelitian Two Factor Design atau sering disebut desain faktorial 2 X 2. Dalam penelitian ini terdapat tiga variabel yang terdiri dari variabel bebas, variabel terikat dan variabel moderator. Variabel bebas adalah konseling kognitif behavioral dengan teknik self management (A1) dan teknik modeling (A2) sebagai variabel perlakuan, variabel moderator adalah ditinjau dari tipe belajar siswa (B), variabel terikat adalah motivasi berprestasi (Y). Populasi dalam penelitian ini adalah siswa kelas X SMA Negeri 1 Kintamani tahun pelajaran 2015/2016 yang secara keseluruhan berjumlah 224 orang yang tersebar dalam 9 kelas. Peneliti mengambil sampel individu sebanyak 90 orang secara acak yang memiliki kecendrungan pada masing-masing tipe belajar, kemudian membaginya menjadi 2 kelompok yaitu untuk kelompok yang diberikan teknik self management dan teknik modeling. Sesuai dengan tujuan penelitian yang telah ditetapkan, maka untuk mengumpulkan data yang sesuai dengan karakteristik dari penelitian ini maka peneliti menggunakan metode angket/kuesioner untuk mendapatkan data mengenai motivasi berprestasi siswa. Disamping itu peneliti juga membuat suatu kuesioner untuk melihat kecenderungan tipe belajar yang dimiliki oleh siswa untuk dapat menentukan sampel. Penyusunan instrumen angket dalam penelitian ini adalah dengan menggunakan skala Likert. Data hasil kuesioner motivasi berprestasi terakhir dianalisis dengan statistika ANAVA dua jalur dan pengujian hipotesis dengan perhitungan uji F pada taraf signifikansi 5\% dengan bantuan program komputer SPSS 16.0.

\section{Hasil Dan Pembahasan}

Temuan empiris pada penelitian ini menyatakan bahwa bahwa terdapat terdapat perbedaan motivasi berprestasi antara kelompok siswa yang mengikuti konseling kognitif behavioral teknik self-management dan teknik modeling. Hasil ini dibuktikan dengan nilai $\mathrm{F}_{\text {hitung }}$ diperoleh sebesar 6,369 dan $\mathrm{F}_{\text {tabel }}$ sebesar 3,96. Jika dibandingkan nilai $\mathrm{F}_{\text {hitung }}$ dengan Ftabel didapatkan bahwa $\mathrm{F}_{\text {hitung }}>\mathrm{F}_{\text {tabel }}$ dengan taraf signifikansi $(\mathrm{p})<0,05$ maka dapat disimpulkan bahwa hipotesis nol yang menyatakan "tidak terdapat perbedaan motivasi berprestasi antara kelompok siswa yang mengikuti konseling kognitif behavioral teknik self-management dan 
teknik modeling", ditolak. Sebaliknya hipotesis alternatif(H1) yang menyatakan bahwa "terdapat perbedaan Motivasi Berprestasi antara kelompok siswa yang mengikuti konseling kognitif behavioral teknik selfmanagement dan teknik modeling", diterima

Untuk uji hipotesis kedua yaitu perbedaan motivasi berprestasi ditinjau dari tipe belajar dibuktikan dengan nilai Fhitung diperoleh sebesar 6,621 dan Ftabel sebesar 3,11. Jika dibandingkan nilai Fhitung dengan Ftabel didapatkan bahwa $\mathrm{F}_{\text {hitung }}>\mathrm{F}_{\text {tabel }}$ dengan taraf signifikansi $(\mathrm{p})<0,05$ maka dapat disimpulkan bahwa hipotesis nol yang menyatakan "tidak terdapat perbedaan motivasi berprestasi ditinjau dari tipe belajar", ditolak. Sebaliknya hipotesis alternatif (H1) yang menyatakan bahwa "terdapat perbedaan motivasi berprestasi ditinjau dari tipe belajar", diterima. Selanjutnya hasil pengujian interaksi konseling kognitif behavioral teknik self management dan teknik modeling dengan tipe belajar terhadap motivasi berprestasi diperoleh $\mathrm{F}_{\text {hitung }}$ diperoleh sebesar 4,002 dan Ftabel sebesar 3,11. Jika dibandingkan nilai $\mathrm{F}_{\text {hitung }}$ dengan $\mathrm{F}_{\text {tabel }}$ didapatkan bahwa $F_{\text {hitung }}>F_{\text {tabel }}$ dengan taraf signifikansi $(p)<0,05$ maka dapat disimpulkan bahwa hipotesis nol yang menyatakan "tidak terdapat pengaruh interaksi konseling kognitif behavioral teknik self management dan teknik modeling dengan tipe belajar terhadap motivasi berprestasi" ditolak. Sebaliknya, hipotesis alternatif (H1) yang menyatakan bahwa "terdapat pengaruh interaksi konseling kognitif behavioral teknik self management dan teknik modeling dengan tipe belajar terhadap motivasi berprestasi", diterima. Jadi, simpulannya adalah terdapat pengaruh interaksi konseling kognitif behavioral teknik self management dan teknik modeling dengan tipe belajar terhadap motivasi berprestasi. Adanya pengaruh interaksi yang signifikan antara konseling kognitif behavioral teknik self management dan teknik modeling dan tipe belajar terhadap motivasi berprestasi.

Oleh karena terdapat pengaruh interaksi yang signifikan antara konseling kognitif behavioral dengan teknik self management dan teknik modeling pada tipe belajar terhadap Motivasi Berprestasi, maka dilanjutkan dengan uji lanjut. Berdasarkan uji lanjut (post hoc) yang dilakukan dengan uji Tukey (uji Tukey dilakukan apabila banyaknya responden atau besarnya sampel pada tiap-tiap sel yang dibandingkan sama) Hasil motivasi berprestasi dikatakan berbeda secara signifikan jika $\mathrm{Q}_{\text {hitung }}>\mathrm{Q}_{\text {tabel }}$ pada taraf signifikansi $5 \%$ atau menolak H0 jika, sebaliknya terima $\mathrm{H} 0$ jika $\mathrm{Q}_{\text {hitung }}<\mathrm{Q}_{\text {tabel }}$ pada taraf signifikansi 5\%. Uji Tukey menghasilkan $\mathrm{Q}_{\text {hitung }}=4,39$ sedangkan harga Qtabel sebesar 2,89. Ternyata $\mathrm{Q}_{\text {hitung }}>\mathrm{Q}_{\text {tabel, }}$, sehingga H0 ditolak. Maka dapat disimpulkan bahwa hipotesis nol yang menyatakan "Tidak terdapat perbedaan motivasi berprestasi antara siswa yang mengikuti konseling kognitif behavioral dengan teknik self management dengan yang mengikuti teknik modeling pada siswa yang memiliki tipe belajar auditori", ditolak.

Untuk mengetahui perbedaan motivasi berprestasi antara siswa yang mengikuti konseling kognitif behavioral dengan self management dan teknik modeling, pada siswa yang memiliki tipe belajar visual diuji dengan uji Tukey. Untuk mengetahui perbedaan motivasi berprestasi antara siswa yang mengikuti konseling kognitif behavioral dengan self management dan teknik modeling, pada siswa yang memiliki tipe belajar auditori diuji dengan uji Tukey. Uji Tukey menghasilkan $Q_{\text {hitung }}=0,96$ sedangkan harga $Q_{\text {tabel }}$ sebesar 2,89 . Ternyata $\mathrm{Q}_{\text {hitung }}<\mathrm{Q}_{\text {tabel}}$, sehingga $\mathrm{H} 0$ diterima maka dapat disimpulkan bahwa hipotesis nol yang menyatakan "Tidak terdapat perbedaan motivasi berprestasi antara siswa yang mengikuti konseling kognitif behavioral dengan teknik self management dengan yang mengikuti teknik modeling pada siswa yang memiliki tipe belajar visual", diterima.

Untuk mengetahui perbedaan motivasi berprestasi antara siswa yang mengikuti konseling kognitif behavioral dengan self management dan teknik modeling, pada siswa yang memiliki tipe belajar kinestetik diuji dengan uji Tukey. Uji Tukey menghasilkan $\mathrm{Q}_{\text {hitung }}=2,80$ sedangkan harga $\mathrm{Q}_{\text {tabel }}$ sebesar 2,89 . Ternyata $\mathrm{Q}_{\text {hitung }}<\mathrm{Q}_{\text {tabel }}$, maka dapat disimpulkan bahwa hipotesis nol yang menyatakan "Tidak terdapat perbedaan motivasi berprestasi antara siswa yang mengikuti konseling kognitif behavioral dengan teknik self management dengan yang mengikuti teknik modeling pada siswa yang memiliki tipe belajar kinestetik, diterima. Sebaliknya, hipotesis alternatif (H1) yang menyatakan bahwa "Terdapat perbedaan motivasi berprestasi 
antara siswa yang mengikuti konseling kognitif behavioral dengan teknik self management dengan yang mengikuti teknik modeling pada siswa yang memiliki tipe belajar kinestetik, ditolak.

\section{Kesimpulan}

Berdasarkan hasil analisis data dan pembahasan hasil penelitian, maka dapat ditarik simpulan sebagai berikut: (1)Terdapat perbedaan motivasi berprestasi antara siswa yang mengikuti konseling kognitif behavioral dengan teknik self management dengan yang mengikuti teknik modeling. (2) Terdapat perbedaan motivasi berprestasi ditinjau dari tipe belajar. (3) Terdapat pengaruh interaksi konseling kognitif behavioral teknik self management dan teknik modeling dengan tipe belajar terhadap motivasi berprestasi (4) Terdapat perbedaan motivasi berprestasi antara siswa yang mengikuti konseling kognitif behavioral dengan teknik self management dengan yang mengikuti teknik modeling pada siswa yang memiliki tipe belajar auditori (5) Tidak terdapat perbedaan motivasi berprestasi antara siswa yang mengikuti konseling kognitif behavioral dengan teknik self management dengan yang mengikuti teknik modeling pada siswa yang memiliki tipe belajar visual (6) Tidak terdapat perbedaan motivasi berprestasi antara siswa yang mengikuti konseling kognitif behavioral dengan teknik self management dengan yang mengikuti teknik modeling Pada siswa yang memiliki tipe belajar kinestetik.

\section{Referensi}

Corey, Gerald. 2009. Teori dan Praktek Konseling dan Psikoterapi. Bandung: PT. Refika Aditama.

Dharsana. 2014. Model-model Teori, Teknik, Skill Bimbingan Konseling untuk Penuliasan RPBK, Proposal, Skripsi, Tesis. Denpasar.

------, 2014. Strategi Modifikasi Kognitif Untuk Mengembangkan Penilaian Kognitif Siswa terhadap Tugas Pelajaran dengan Menggunakan Model Cormier dan Cormier (studi eksperimental dengan siswa kelas 1 SMA KORPRI IKIP Bandung tahun 1997). Denpasar.

Gunarsa, Singgih. 2004. Konseling dan Psikoterapi. Jakarta: PT. BPK Gunung Mulia.

Komalasari, Gantina, Wahyuni dan Karsih. 2011. Teori dan Teknik Konseling. Jakarta: PT. Indeks.

Nasution, S. 2014. Sosiologi pendidikan. Jakarta: Bumi Aksara.

Nelson, Richard dan Jones. 2011. Teori dan Praktik Konseling dan Terapi (edisi ke empat). Yogyakarta: Pustaka Pelajar. Nursalim, Mochamad. 2013. Strategi \& Intervensi Konseling. Jakarta: Indeks.

Robbins dan Judge. 2007. Perilaku Organisasi (Organizating Behavior). terj. Diana Angelica. Jakarta : Salemba Empat (Elektronic-Book)

Sopya Yanti, Ayu Putu.2013. Penerapan Model Konseling Behavioral Teknik

Modeling untuk Mengembangkan Sikap Empati Siswa Kelas XC UPW SMKN 1 Singaraja. Singaraja: Universitas Pendidikan Ganesha 
The authors declare that they have no significant competing financial, professional or personal interests that might have influenced the performance or presentation of the work described in this manuscript.

First Publication Right: BISMA The Journal of Counseling

https://doi.org/10.xxxx/ $x \times x x x$

Open Access Article | CC-BY Creative Commons Attribution 4.0 International License.

Word Count: 